"The submitted manuscript has been authored by a contractor of the U.S. Government under contract No. DE-AC05-96OR22464. Accordingly, the U.S. Government retains a nonexclusive, royalty-free license to publish or reproduce the published form of this contribution, or allow others to do so, for U.S. Government purposes."

\title{
Overview of the IFMIF Test Cell Design
}

By

A. Moslang and E. Daum

Forschungszentrum Karlsruhe, Institute of Materials Research I

J. R. Haines and D. M. Williams Oak Ridge National Laboratory

I. GoS. Jitsukawa and K. Noda

S. CEC-IAM-HFR, The Netherlands<smiles>CC(C)(C)C(C)(C)C1CC1</smiles>

Presented at the

12th Topical Meeting of the American Nuclear Society Reno, NV

June 16-20, 1996 


\section{DISCLAIMER}

Portions of this document may be illegible in electronic image products. Images are produced from the best available original document. 


\section{DISCLAIMER}

This report was prepared as an account of work sponsored by an agency of the United States Government. Neither the United States Government nor any agency thereof, nor any of their employees, makes any warranty, express or implied, or assumes any legal liability or responsibility for the accuracy, completeness, or usefulness of any information, apparatus, product, or process disclosed, or represents that its use would not infringe privately owned rights. Reference herein to any specific commercial product, process, or service by trade name, trademark, manufacturer, or otherwise does not necessarily constitute or imply its endorsement, recommendation, or favoring by the United States Government or any agency thereof. The views and opinions of authors expressed herein do not necessarily state or reflect those of the United States Government or any agency thereof. 


\title{
OVERVIEW OF THE IFMIF TEST CELL DESIGN
}

\author{
A. Möslang, E. Daum \\ Forschungszentrum Karlsruhe, Institute of Materials Research I, P.O. Box 3640, D-76021, Karlsruhe, Germany \\ J. R. Haines, D.M. Williams \\ Oak Ridge National Laboratory, P.O. Box 2009, Oak Ridge, TN 37831-8071 \\ S. Jitsukawa, K. Noda \\ Japan Atomic Energy Research Institute, Tokai-mura, Ibaraki-ken, 319-11, Japan \\ R. Viola \\ CEC-IAM-HFR P.O. Box 2, 1755 ZG Petten, The Netherlands
}

\begin{abstract}
The Conceptual Design Activity (CDA) for the International Fusion Materials Irradiation Facility (IFMIF) has entered its second and final year, and an outline design has been developed. Initial evaluations of the potential of this high flux, high intensity D-Li source have shown that the main materials testing needs can be fulfilled. According to the materials testing needs, Vertical Test Assemblies will accommodate test modules for the high flux ( 0.5 liter, $20 \mathrm{dpa} / \mathrm{a}, 250-1000^{\circ} \mathrm{C}$ ), the medium flux (6 liter, 1-20 $\mathrm{dpa} / \mathrm{a}, 250-1000^{\circ} \mathrm{C}$ ), the low flux (7.5 liter, 0.1-1 dpa/a), and the very low flux (> 100 liter, $0.01-0.1 \mathrm{dpa} / \mathrm{a}$ ) regions. Detailed test matrices have been defined for the high and medium flux regions, showing that on the basis of small specimen test technologies, a database for an engineering design of an advanced fusion reactor (DEMO) can be established for a variety of structural materials and ceramic breeders. The design concepts for the Test Cell, including test assemblies, remote handling equipment and Hot Cell Facilities with capacity for investigating all irradiation specimens at the IFMIF site are described.
\end{abstract}

\section{INTRODUCTION}

The (IFMIF) Conceptual Design Activity was started in 1994 under sponsorship of the International Energy Agency (IEA). The mission of this study is to provide a high-flux, high-intensity neutron irradiation testing facility for fusion materials research and development. The specific goal of the IFMIF project is (i) to provide a neutron source with an energy spectrum simulating that for a fusion reactor first wall/blanket at sufficient intensity and irradiation volume to test samples of candidate materials up to about full lifetime of anticipated use mainly in a fusion DEMO reactor, and (ii) to calibrate data generated from fission reactors and other simulation experiments with light or heavy ions. Earlier efforts investigating this type of facility $[1,2]$, including the Fusion Materials Irradiation Test (FMIT) facility project [3], have concluded that the technically most feasible approach for providing the necessary test conditions utilizes a high-energy deuteron beam, which generates neutrons in a nuclear stripping reaction with a liquid lithium target. The average energy of the deuteron beam is presently specified to be $35 \pm 5 \mathrm{MeV}$ with an energy distribution of $\pm 0.5 \mathrm{MeV}$ about its average value. The deuteron beam current is $250 \mathrm{~mA}$, which is provided by two accelerators, each operating at $125 \mathrm{~mA}$. The cross-sectional shape of the beam at the lithium target is a rectangle with dimensions of 50 by $200 \mathrm{~mm}$. The high-flux test volume, i.e. volume which has an irradiation damage rate for iron of greater than $20 \mathrm{dpa} / \mathrm{a}$, is required to be $0.5 \mathrm{~L}$. It will be shown that in contrast to concepts of earlier neutron sources, IFMIF will also provide sufficiently large test beds in lower flux regions for a variety of instrumented and/or in situ experiments in metals and non metals. This paper addresses the design concept and critical issues for the materials Test Facilities system for IFMIF.

\section{USER REQUIREMENTS}

Besides the necessity for a reasonably high flux volume, one of the most critical questions for the selection of suitable neutron sources is the effect of neutron spectrum on relevant materials parameters like primary recoil spectrum, displacement damage rate and gaseous as well as solid transmutation rates. Although up to about $30 \%$ of all the neutrons generated by $40 \mathrm{MeV}$ deuterons have energies above $14 \mathrm{MeV}$ as recent advanced neutronics calculations have shown, the D-Li neutron spectrum is considered to meet essential fusion neutron spectrum requirements. Other requirements for an intense neutron source include neutron flux gradients $<10 \% / \mathrm{cm}$ inside the specimen, a neutron beam availability of $70 \%$ and a quasi continuous operation [4].

Neutron flux calculations for the Test Cell suggest that the high flux region, equivalent to $9.0 \times 10^{17} \mathrm{n} / \mathrm{m}^{2}-\mathrm{s}\left(\mathrm{E}_{\mathrm{n}}=\right.$ $14 \mathrm{MeV}$ ) or $2 \mathrm{MW} / \mathrm{m}^{2}$, will have a volume of about 0.5 liters [5]. Therefore it is clear that extensive use of miniaturized specimens will be required for the IFMIF tests 
and that only a limited number of materials can be tested. Establishment of a complete materials database for construction of a demonstration commercial fusion power plant (DEMO) will certainly require extensive use of both IFMIF and fission reactor irradiation sources. It is assumed that fission reactor facilities will continue to be available to perform scoping irradiation tests on experimental or innovative alloys and that IFMIF will only be used to test materials that have demonstrated good radiation resistance during medium to high dose (30-50 dpa) fission neutron irradiation. In the following, the four different flux regions are discussed briefly together with the dedicated materials to be irradiated. A tentative list of materials, test conditions, irradiation temperatures, and displacement damage doses for the different flux regions of IFMIF is given in Table $I$.

1. High flux region. In order to evaluate whether the volume of 0.5 liter is adequate to obtain the necessary materials property data, detailed test matrices have been elaborated [6] for a high flux reference test module based on a set of seven types of specimens with "baseline" geometries. This effort relies heavily on a previous evaluation performed in 1993. However, the ongoing support of the Small Specimen Test Technology Community (SSTT) is indispensable for an effective use of the irradiation volume, for any necessary correlations with macroscopic specimens, and for some international standardization of selected test techniques. Independent of the coolant to be used, all seven types of specimens will be encapsulated in packets containing one to six specimens, except the TEM disc packets, which will contain up to about 80 specimens. The total volume occupied by the packets (irradiation rigs in case of $\mathrm{He}$ gas coolant) is estimated to be $325 \mathrm{~cm}^{3}$ for the NaK cooled test module and $340 \mathrm{~cm}^{3}$ for the He gas cooled version.

Ferritic/martensitic steels, vanadium alloys, and $\mathrm{SiC} / \mathrm{SiC}$ composites are the three leading candidates in the global Fusion Materials Technology Programs for the first wall and blanket structure of DEMO, and are therefore used as the basis for the high flux test matrix. Two to three variants of each of these materials are included together with a limited number of unspecified alternative materials ("innovative alloys"). It is unlikely that this specimen matrix can be significantly reduced, because IFMIF must meet the needs of more than one DEMO design. Considering the reference availability for IFMIF of $70 \%$, the high flux region would produce a damage level of $\sim 15$ dpa in vanadium and ferritic/martensitic steel in one calendar year. Therefore, approximately 10 years would be required to achieve a DEMO-relevant lifetime dose of $\sim 150$ dpa. At least six different irradiation temperatures are necessary: 300,400 and $500{ }^{\circ} \mathrm{C}$ for ferritics, 400,500 and $600{ }^{\circ} \mathrm{C}$ for vanadium alloys, and 600,800 and $1000{ }^{\circ} \mathrm{C}$ for $\mathrm{SiC} / \mathrm{SiC}$ composites. Significant modifications of the present test matrix might occur if the number of reference materials to be tested in IFMIF change, or if the final recommendation of the SSTT community with respect to specimen number and size will be different from numbers assumed up to now. Nevertheless, the evaluations of the available high flux test volume for IFMIF have shown, that the relatively small volume of the high-flux region of about 0.5 liter is adequate to obtain for a couple of first wall and blanket structural materials a design relevant engineering database up to $150 \mathrm{dpa}$.

2. Medium and low flux regions. The majority of specimens made of structural materials will be irradiated in the high flux region followed by post irradiation

Table I

IFMIF Flux Regions, Reference Materials, and Irradiation Conditions

\begin{tabular}{|c|c|c|c|c|c|}
\hline $\begin{array}{l}\text { Flux region } \\
\text { (Damage rate) }\end{array}$ & $\begin{array}{l}\text { Volume } \\
\text { (Liter) }\end{array}$ & Materials and Type of Experiments & $\begin{array}{l}\text { Irradiation } \\
\text { Temp. }\left({ }^{\circ} \mathrm{C}\right)\end{array}$ & $\begin{array}{l}\text { Damage dose } \\
\text { (dpa) }\end{array}$ & $\begin{array}{c}\text { Test Module } \\
\text { Coolant }\end{array}$ \\
\hline $\begin{array}{l}\text { High flux } \\
(>15 \mathrm{dpa} / \mathrm{a})\end{array}$ & 0.5 & $\begin{array}{l}\text { Structural Materials: } \\
\text { - Ferritic/Martensitic Steels } \\
\text { - Vanadium Alloys } \\
\text { - SiC/SiC Composites }\end{array}$ & $\begin{array}{l}300,400,500 \\
400,500,600 \\
600,800,1000\end{array}$ & $\begin{array}{l}<150 \\
<150 \\
<150\end{array}$ & $\begin{array}{l}\mathrm{NaK} \\
\mathrm{NaK} \text { (He gas) } \\
\text { He gas }\end{array}$ \\
\hline $\begin{array}{l}\text { Medium flux } \\
(15-1 \mathrm{dpa} / \mathrm{a})\end{array}$ & 6 & $\begin{array}{l}\text { Fully Instrumented In situ Experiments: } \\
\text { - Creep-Fatigue on Structural Materials }\end{array}$ & 25 & 5 & $\mathrm{He}$ \\
\hline $\begin{array}{l}\text { Low Flux } \\
(1-0.1 \mathrm{dpa} / \mathrm{a})\end{array}$ & 7.5 & $\begin{array}{l}\text { - Tritium Release on Ceramic Breeders } \\
\text { - Ceramic Insulator Materials }\end{array}$ & $\begin{array}{c}250-700 \\
0-500\end{array}$ & $\begin{array}{c}1-50 \\
0.1-10\end{array}$ & $\begin{array}{l}\text { He gas } \\
\text { He gas }\end{array}$ \\
\hline $\begin{array}{l}\text { Very low flux } \\
(0.1-0.01 \mathrm{dpa} / \mathrm{a})\end{array}$ & $>100$ & $\begin{array}{l}\text { Instrumented Capsules } \\
\text { - RF Windows } \\
\text { - Diagnostic Materials } \\
\text { - Superconducting Materials }\end{array}$ & $\begin{array}{c}0-400 \\
0-400 \\
(-270)-(-170)\end{array}$ & $\begin{array}{c}0.1-5 \\
0.001-10 \\
<0.1\end{array}$ & $\begin{array}{l}\mathrm{He} \text { gas } \\
\mathrm{He} \text { gas } \\
\mathrm{LN}_{2}, \mathrm{LHe}\end{array}$ \\
\hline
\end{tabular}


examinations in Hot Cells. This is the normal procedure used to generate the design database. However, additional, more sophisticated experiments are necessary to measure the materials data properly under real loading conditions. Several in situ mechanical tests [7] from high energy light ion irradiation facilities indicate, that the material response on simultaneous long term irradiation and mechanical loading cannot be simulated by conventional postirradiation tests and that some in situ experiments are mandatory for development of structural materials. Selected in situ push-pull (creep-) fatigue and stress corrosion tests on structural materials can also confirm whether the bulk of post-irradiation data is conservative with respect to real fusion conditions.

Most of the fusion blanket designs utilize continuous tritium recovery during operation. Among other properties the performance of blankets with ceramic breeders depends sensitively on irradiation durability, structural integrity, and tritium diffusion and release rates under fusion relevant neutron spectra. Thus, in situ tritium release experiments up to the expected lifetime, which are followed by PIE to investigate degradation of properties, tritium inventory etc., are very important for fusion breeding blanket designs. All in situ tritium release experiments will be carried out with carefully controlled temperature and sweep gas composition.

A variety of other instrumented experiments will be necessary at the IFMIF site. Excitation of electrons due to neutron irradiation causes radiation induced conductivity (RIC) during irradiation. Furthermore, a very large permanent decrease of the electrical resistivity, called radiation induced electrical degradation (RIED) may occur in some ceramic insulators if an electrical field is applied during irradiation. Thus, continuous electrical resistivity measurements of insulating ceramics under fusion relevant irradiation conditions needs to be done. Other in situ tests include measurement of the dielectric properties of candidate RF window materials at different temperatures, the properties of optical fiber and optical windows under irradiation, or the irradiation behavior of superconducting magnet materials and polymer insulation. In general, the low and very low flux regions of the IFMIF test cells need to be flexible to accommodate any unforeseen in situ experiments or mockup tests of components.

\section{TEST CELL DESIGN CONCEPT}

As shown in Fig. 1, the IFMIF Test Cell contains (1) two vertically oriented test assemblies, referred to as Vertical Test Assemblies (VTAs) 1 and 2, which support the test modules used for long-term irradiation of specimens in the high and medium flux regions, (2) an array of tubes, referred to as Vertical Irradiation Tubes (VITs), used for inserting test capsules in the low and very low flux regions, (3) a vacuum liner that encloses the test modules and also accommodates the lithium target, (4) a $0.3-0.5 \mathrm{~m}$ thick stainless steel heat shield surrounding the liner to protect the concrete neutron shielding from overheating, (5) the Test Cell Removable Cover, which can be lifted with an overhead crane to gain access to the entire Test Cell, and (6) a seal plate for providing a vacuum seal between the removable vertical test assemblies and the Removable Cover.

VTA 1 contains the 0.5 liter High-Flux Module. The shielding portion of the VTAs consists of a stepped, stainless steel liner that is filled with concrete. Steps in the Test Cell shield plug conform to the steps in the shielding portion of each VTA to prevent radiation streaming. The coolant supply and return lines for the High Flux module are contained within the shielding body of VTA 1 . Conceptual designs for both helium cooled and $\mathrm{NaK}$ cooled versions of this test assembly have been developed. Although the detailed arrangement and temperature control of test specimens is quite different for these two coolant schemes, the overall configuration for VTA 1, as shown in Fig. 2, is nearly identical for both coolants. The VTAs

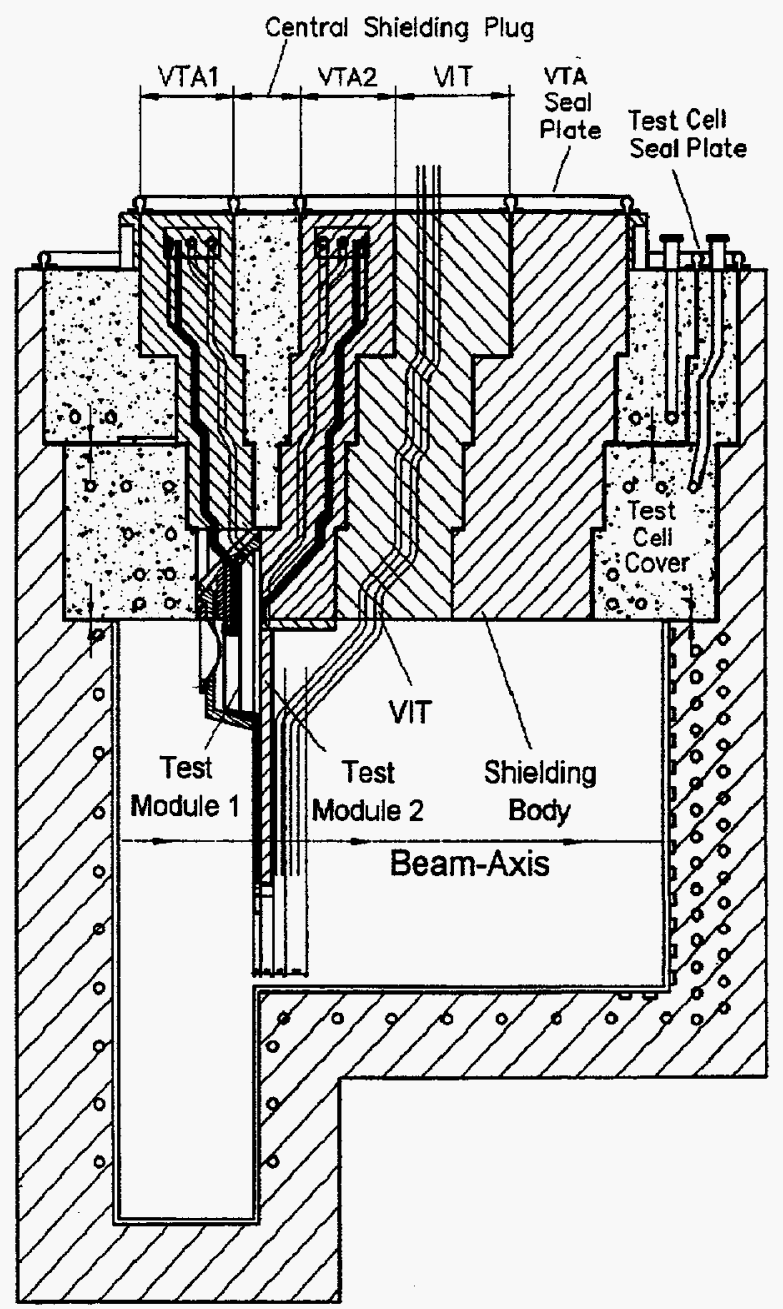

Fig. 1. Elevation view of the Test Cell 
can be removed and replaced with vertical access. The Central Shielding Plug, shown in Fig. 1, must be removed prior to lifting either VTA.

VTA 2 is located directly behind the high-flux module and houses the medium-flux experiments. The useful volume of VTA 2, i.e. volume with a damage rate of greater than $1 \mathrm{dpa} / \mathrm{a}$ for iron, is 6 liters. Several different types of in-situ tests are anticipated to be performed in the medium-flux region, including creep fatigue testing of structural materials, tritium release performance tests of ceramic breeder materials, and electrical conductivity tests on ceramic insulators. In addition, it is likely that some irradiations of vacuum vessel structural materials and functional (mostly ceramic) materials may be performed in VTA 2. Gaseous helium will be used be used as the medium-flux module coolant for all irradiation temperatures since the available irradiation volume is rather large, and tritium released from ceramic breeding materials can be easily separated from helium. A concept for the push-pull testing machine required to examine the creep fatigue behavior of structural materials during irradiation in inert or chemical environments is shown in Fig. 3.

Three creep fatigue specimens may be tested at one time in this apparatus. Each specimen is a hollow tube with coolant flow in the specimen interior to maintain uniform temperature. Chemical environments such as liquid metal coolants may be selected to examine the impact of stress corrosion processes on the creep fatigue and stress corrosion cracking behavior during irradiation. It is not certain if water coolant tests can be performed in the Test Cell because of safety concerns with the lithium and NaK liquid metals. The approximate size of the in-situ test

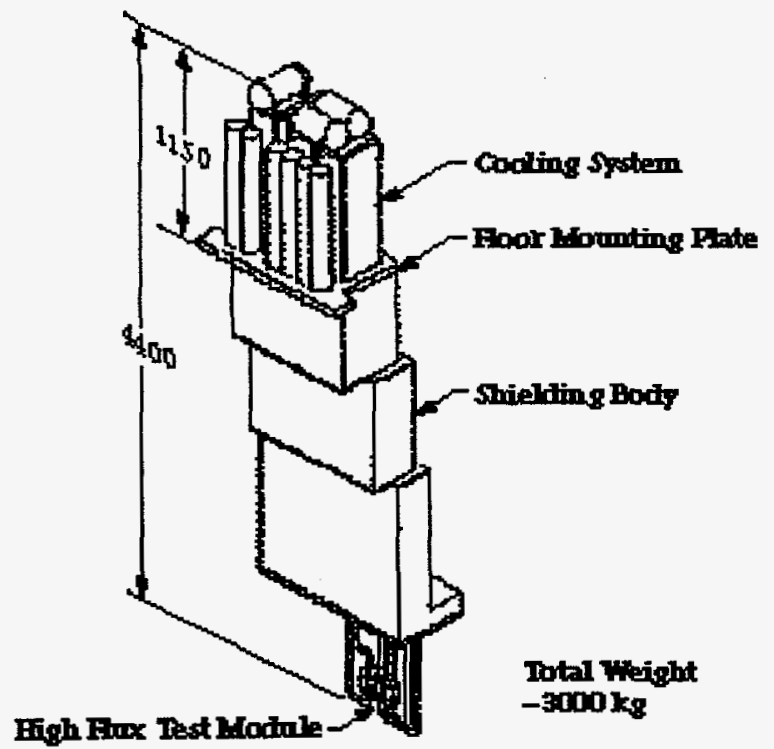

Fig. 2. Design configuration for VTA 1 including the high-flux Test Module (dimensions shown in millimeters). equipment is $100 \mathrm{~mm}$ high, $85 \mathrm{~mm}$ thick, and $400 \mathrm{~mm}$ wide. A total of 6 coolant pipes and 15 electrical wires for thermocouples and load-displacement signals are required. Three actuators for loading the specimens and the piping for the actuators are also installed in VTA 2.

Tritium release performance tests of ceramic breeder materials using test modules configurations such as that shown in Fig. 4 are also planned for VTA 2. These experiments will use specimens in the shapes of disks, pellets, and pebbles that are contained in subcapsules.

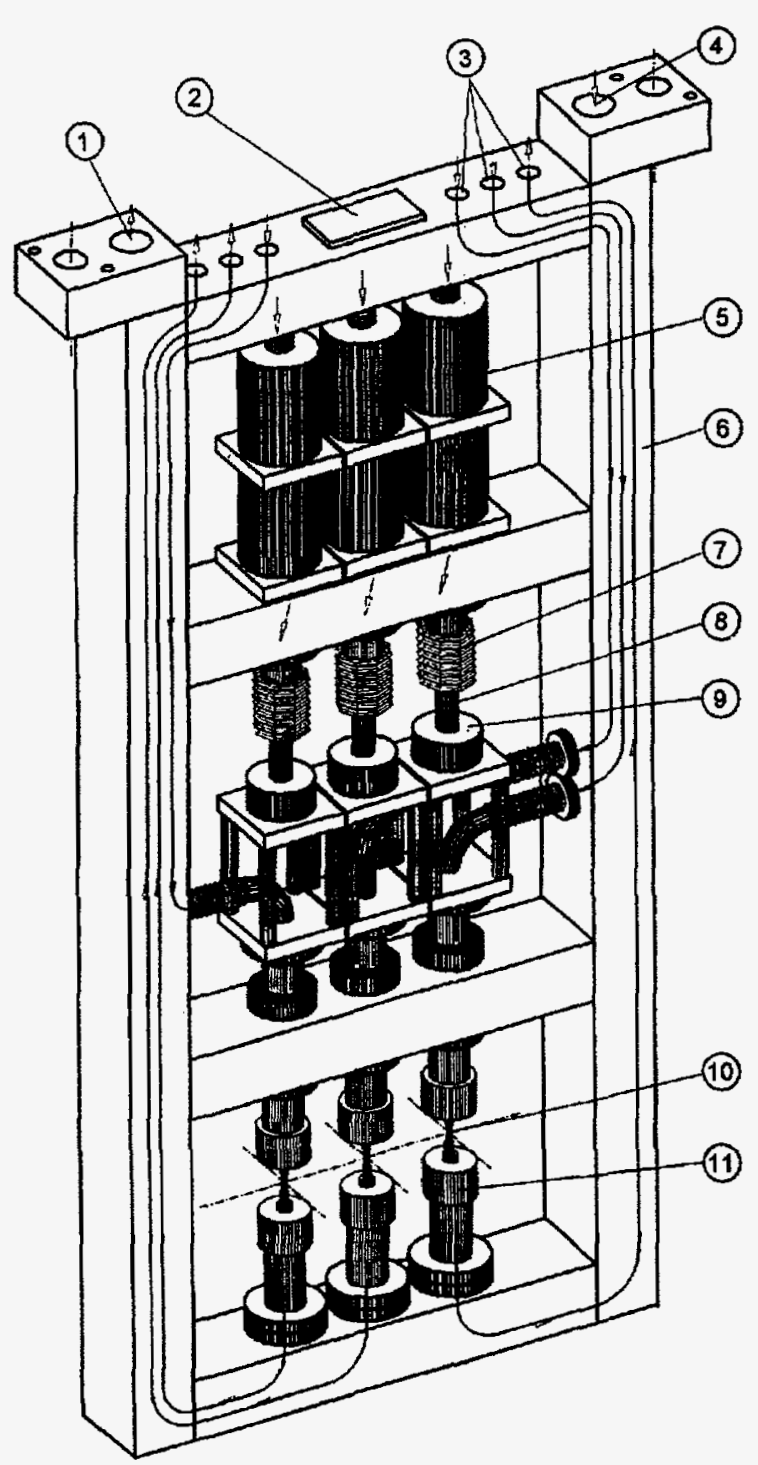

Fig. 3. Universal testing machine (test module 2) for in situ creep-fatigue experiments on three individual specimens in the medium flux position. Coolant $(1)(3)(4)$, plug unit (2), rod drive (5), frame (6), bellows (7), push pull rod (8), load cell (9), specimen (10), screw cap (11). 
Tritium released by the specimens in the subcapsules will be swept up by helium gas flowing through the subcapsules and will be carried through pipes in the VTA to measuring equipment located elsewhere in the Test Cell Facilities. The tritium release test capsule would be $\sim 240$ $\mathrm{mm}$ high, $65 \mathrm{~mm}$ thick and $120 \mathrm{~mm}$ wide and would contain eight separate subcapsules. The subcapsules would be irradiated at temperatures ranging from $300^{\circ} \mathrm{C}$ to $900^{\circ} \mathrm{C}$, with temperature control achieved by means of helium gas gaps.

The Vertical Irradiation Tube (VIT) system, which consists of an array of tubes, pneumatic pumps, valves and heat exchangers, is designed for rapid insertion and removal of test specimens in the low and very low flux regions of the Test Cell. The array of tubes, illustrated in Fig. 5, contains pneumatic capsules that remain in the irradiation

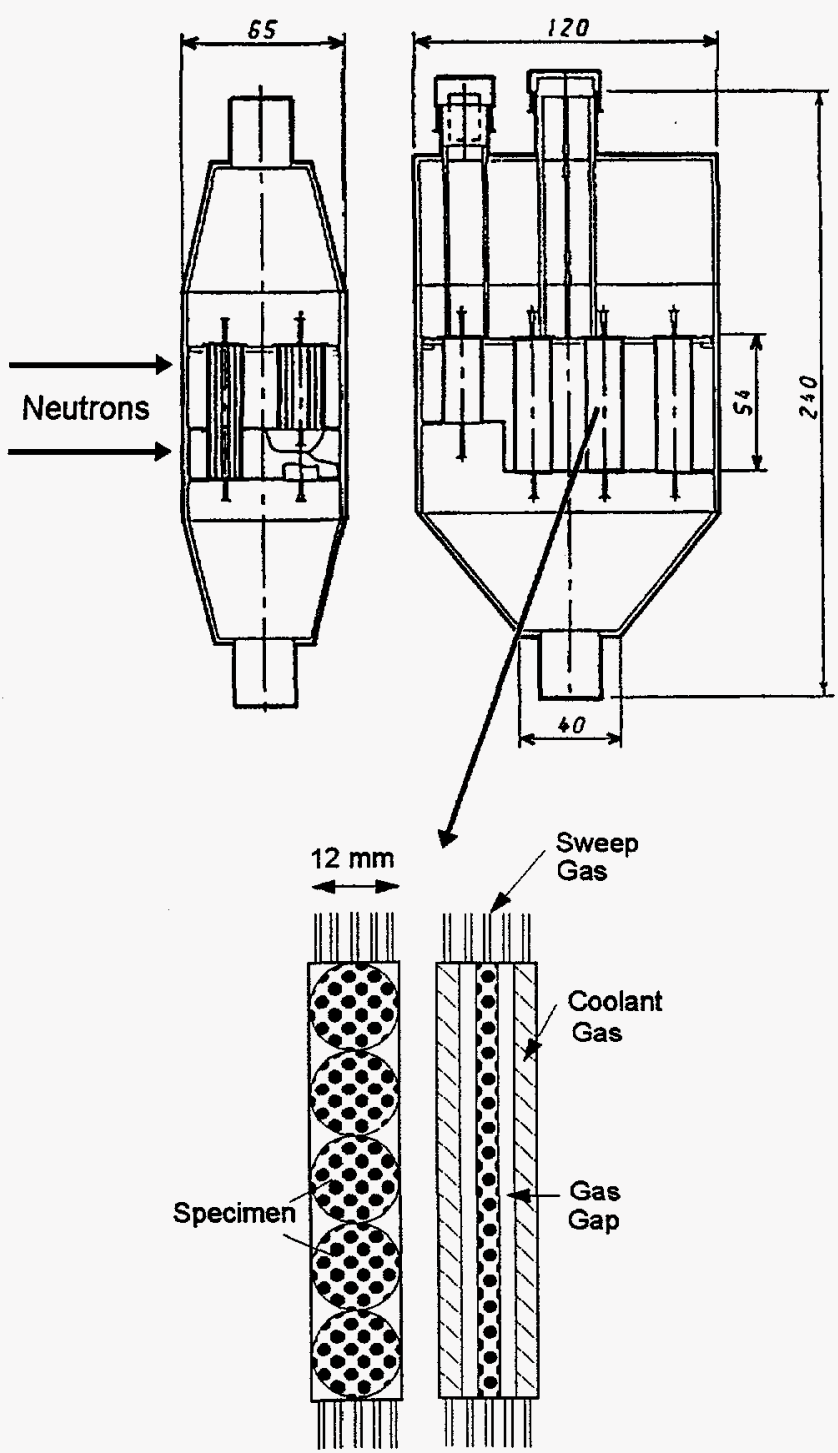

Fig. 4. Test module 2 for in-situ tritium release experiments on ceramic breeder materials in the medium flux position. region until the specimens are irradiated to the desired dose. The pneumatic capsules are then transported back to the loading/unloading station where they are removed and placed into a shielded container and transported to the PIE hot cells. A thermal control system is provided that can accurately maintain and control test specimen temperatures within individual tubes during irradiation, each operating at a different temperature ranging from $4 \mathrm{~K}$ to $800 \mathrm{~K}$.

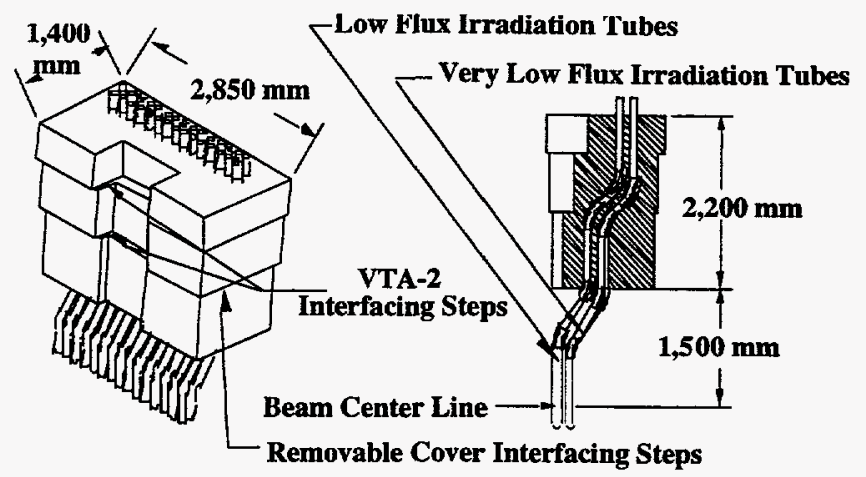

Fig. 5: Vertical Irradiation Tube (VIT) plug for instrumented capsules with special purpose materials for the low and very low flux position.

\section{HOT CELLS AND POST IRRADIATION EXAMINATION FACILITIES}

The present design concept implies that after disassembling the test modules, all irradiated specimens and materials of interest will be investigated in suitable PostIrradiation Examination (PIE) Facilities at the IFMIF site. A plan view of the Test Facilities (excluding the Tritium Laboratory) is shown in Fig. 6.

The Access Cell is located directly above the Test Cells and contains the helium gas coolant loops for VTAs and various remote handling equipment like telescopic master/slave manipulators and a universal robotic system. The latter is the main device for routine VTA removal and reloading operations, for exact insertion of the test cell cover or the shield plugs, and for maintenance operations e.g. operations on the lithium-target inside the Test Cell. After irradiation the VTAs are removed and transported with the help of a transfer rail system into a large Service Cell, which is primarily dedicated to the assembly and disassembly of the test modules to the VTAs. In addition, its equipment allows maintenance work on the VTAs and the Li-target components. In the Test Module Handling Cell located immediately adjacent to the Service Cell, packets or rigs containing the individual specimens will be removed from the test modules, and the capsules will be cut open to retrieve the irradiated specimens. Finally, the irradiated specimens will be sent usually with a tube 


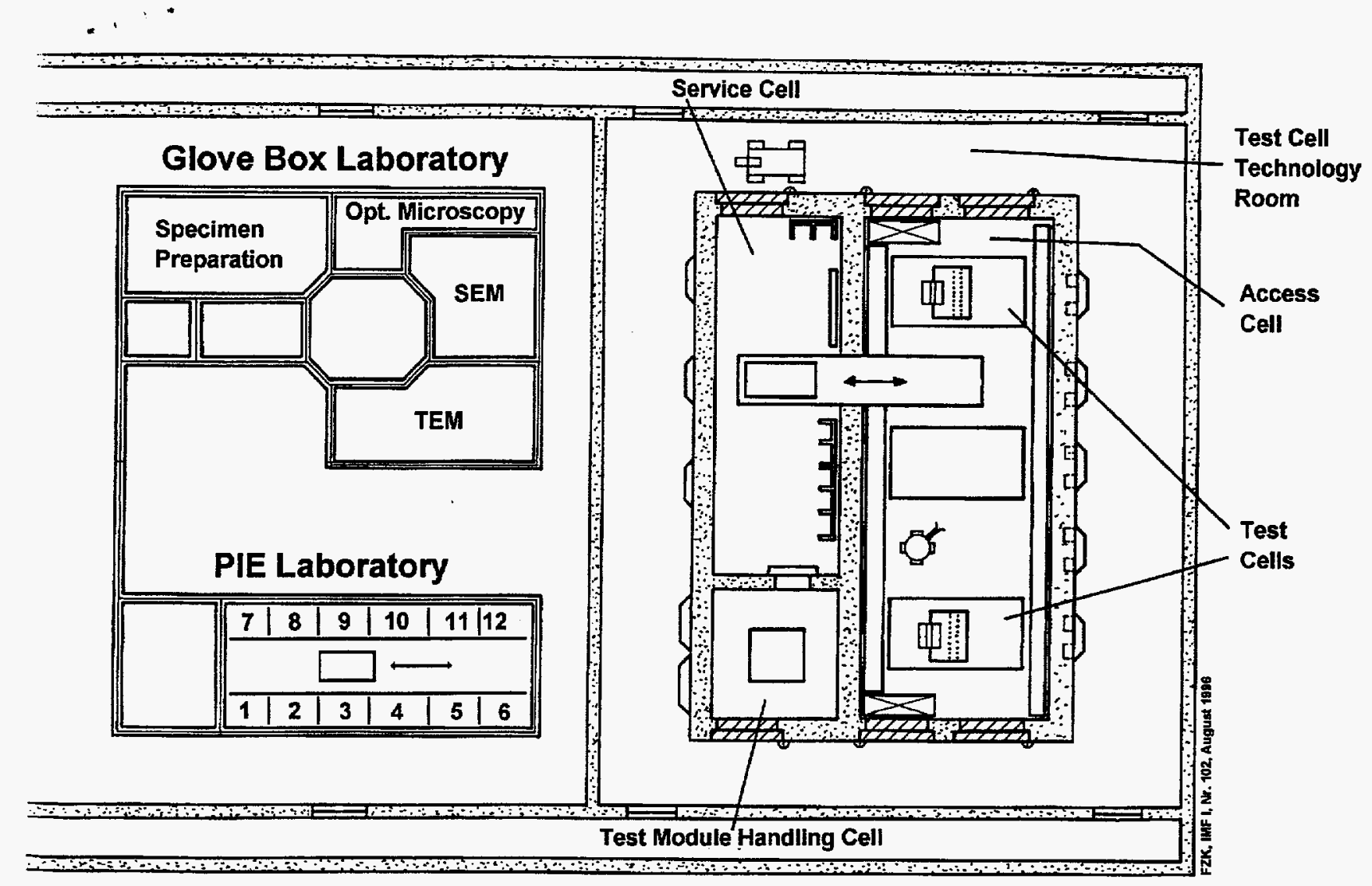

Fig. 6: Plan view of the Test Facilities.

mailing system to the PIE Facilities. The PIE Facilities dedicated to the users for qualified analyses include

1) the PIE Laboratory, an array of testing equipment in one single Hot Cell for mechanical testing of conventional, nontritiated high level radioactive specimens

2) Shielded Glove Box Laboratory for microstructural analyses of small or low dose nontritiated metals and nonmetals,

3) the Tritium Laboratory for the investigation of tritium contaminated or tritium containing specimens and components.

1. PIE Laboratory: Although the specimens irradiated in the high and medium flux regions of the Test Cell will usually be miniaturized, the activity will be sufficiently high that PIE must be performed in hot cells for high level radioactive specimens. A modular type design is being considered with a smaller maintenance room for personnel access, and the actual hot cell consisting of equipment, tools, similar sized testing machines, and a removable exchange system with a small bridge crane and a transfer lorry. The removable testing machines are standing side by side in two arrays and can be rapidly replaced or exchanged to carry out service in the attached maintenance room. The bulk of the test equipment in this hot cell is dedicated to mechanical tests of specimens irradiated in the high flux region. Therefore, the PIE Hot Cell includes a laser profilometry device for pressurized creep tube tests and several universal testing machines equipped with vacuum furnaces and heating systems for tensile tests, push-pull creep fatigue tests, corrosion fatigue tests, fatigue crack growth and fracture toughness tests. Based on the preliminary test matrix mentioned in section II, the average yield per year from the high flux region is 220 specimens, and an additional 370 TEM disk samples. The overall test capacity will ensure, that the examinations on these irradiated specimens together with necessary tests on unirradiated aged specimens will be less time consuming than the irradiation itself.

2. Shielded Glove Box Laboratory. Microstructural analyses will be indispensable to describe and understand the irradiation induced defects and their impact on materials properties. Because only very small specimen sizes are necessary for these analyses, shielded glove boxes are sufficient. According to international standards, this Laboratory will be equipped with 10 bench-top glove boxes, modern scanning and transmission electron microscopes (SEM and TEM), TEM specimen preparation tools, an optical microscope, a microhardness tester, a temporary vacuum storage grid for TEM specimens, and an 
. i -

activation analysis system. The latter is important to confirm experimentally on low and reduced activation materials the predictions from activation inventory codes.

3. Tritium Laboratory. The test module irradiated in the medium flux region will contain ceramic breeders like $\mathrm{Li}_{4} \mathrm{SiO}_{4}, \mathrm{Li}_{2} \mathrm{O}, \mathrm{Li}_{2} \mathrm{TiO}_{3}$ or other innovative lithium based ceramics with considerable tritium content. Retrieval of tritium containing specimens from subcapsules and PIE of highly gamma-ray activated ceramic breeders requires suitable hot cells. To minimize any cross contamination and to assure effective tritium retention, hot cells for tritium contaminated and containing materials are separated from that of other materials. Fig. 7 shows a bird's eye view of the main subsystems of the Tritium Facility: (i) the airtight tritium handling hot cells for disassembling, preparation of specimens and PIE of activated specimens, (ii) the airtight tritium glove boxes to analyze small pieces or low activated ceramic breeders, and (iii) the temporary storage for tritiated specimens and devices. Detailed layouts have been developed for tritium processing systems with effective detritiation and effluent tritium removal subsystems. In the present design $20 \mathrm{~m}^{3} / \mathrm{h}$ tritiated gas and $1000 \mathrm{Ci} /$ day can be processed.

\section{CONCLUSIONS}

Detailed conceptual designs have been developed for all subsystems of the Test Cell Facilities, showing that in accordance with the mission of IFMIF, all major users requirements can be fulfilled. In order to meet several safety

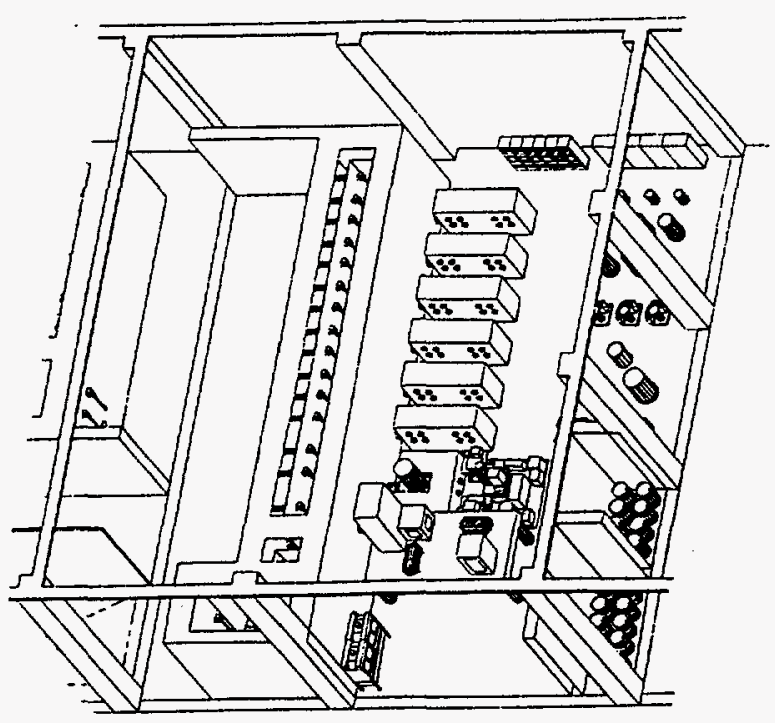

Fig. 7. Bird's-eye view of the Tritium Laboratory with Hot Cells (left hand side), glove boxes and examination equipment (middle) as well as specimen and waste storage (right hand side). and reliability requirements, the neutron generating $\mathrm{Li}$ target and all irradiation modules are accommodated in a vacuum chamber with an area of $3 \mathrm{~m}$ by $4 \mathrm{~m}$ and a height of $2.5 \mathrm{~m}$. This test cell has an actively cooled steel liner and a removable shield plug with individual ports which allows flexible installation of several vertical test assemblies (VTAs). Three different vertical assemblies considered in the present design are dedicated to a broad spectrum of loading conditions in metals and non metals. Reference materials testing programs were formulated for the high and medium flux regions. Using miniaturized specimens, a database with damage doses up to DEMO reactor relevant levels of $150 \mathrm{dpa}$ can be achieved in several candidate structural materials irradiated in the high flux region. The medium flux region is mainly dedicated to instrumented in situ creep-fatigue tests on structural materials and to in situ tritium release experiments on various ceramic breeder materials, while in the low flux regions special purpose materials will be irradiated in instrumented capsules. Detailed layouts for several complete test assemblies for post-irradiation and in situ experiments using either $\mathrm{NaK}$ or inert gas as the coolant were developed together with design concepts for remote handling and Hot Cell Facilities with capacity for investigating all irradiation specimens on the IFMIF site.

\section{REFERENCES}

[1] A. Miyahara and F.W. Wiffen (Edrs), Proceedings of the International Panel on $14 \mathrm{MeV}$ Intense Neutron Source based on Accelerators, Tokyo, Jan 14-16, 1991, NIFS-W2-2 Report 1991.

[2] K. Ehrlich, E. Daum (Edrs), Proceedings of the IEA Workshop on Intense Neutron Sources, Karlsruhe, Sept. 21-23 1992; KfK report 5296, May, 1994.

[3] A. L. Trego et al., "Fusion Materiais Irradiation Test Facility for Fusion Materials Qualification," Nuc. Tech. Fusion, 4, 695-700 (1983).

[4] T. Kondo, T. Shannon and K. Ehrlich; $8^{\text {th }}$ Intern. Conf. on Fusion Reactor Materials (ICFRM-8), Obninsk, Russia, Sept. 25-29 1995, to be published in Journ. Nucl. Matter.

[5] I.C. Gomes, Y. Oyama in Proceedings of the IEA technical Workshop on the Test Cell System for Intern. Fusion Materials Irradiation Facility; Karlsruhe, July 36 1995; Editors: A. Möslang, R. Lindau, FZKA report 5633 (1995), p. $51 \mathrm{ff}$.

[6] S. Jitsukawa, S. Zinkle; ibid, p.131ff.

[7] R. Lindau, A. Möslang, Journ. Nucl. Mater., 212-215 (1994), p. 599. 